\title{
STUDI PEMANFAATAN TUMBUHAN OBAT SEBAGAI TONIK OLEH PENGOBAT TRADISIONAL DI DESA KARYA BAKTI KECAMATAN SUNGAI BETUNG KABUPATEN BENGKAYANG
}

\author{
(The study of The Utilization of Medicinal Plants Used by Traditional Healers in Karya Bakti \\ Village, Sungai Betung Sub-Distric, Bengkayang Regency)
}

\author{
Riconadi, Yanieta Arbiastutie, Yeni Mariani, Lolyta Sisillia, Fathul Yusro \\ Fakultas Kehutanan, Universitas Tanjungpura, Jalan Imam Bonjol Pontianak 78124 \\ Email: riconadi96@gmail.com
}

\begin{abstract}
There is a long history of the plant's usage as medicine to overcome various diseases and maintain people's health conditions in communities. Among its multiple benefits, medicinal plants are also used to strengthen the body organs (tonic). The use of medicinal plants as tonics is still carried out by the society of Karya Bakti Village, Sungai Betung District, Bengkayang Regency, especially by traditional healers (dukun) who are trusted by the community to help treat various diseases. This study aims to analyze plant's use by traditional healers in Karya Bakti Village, Bengkayang Regency. The data was collected by interviewing two traditional healers who were selected based on the snowball sampling technique. The interview results revealed that the village's traditional healer used 32 species of medicinal plants belonging to 25 families. The most widely used plant family is Zingiberaceae (19\%), with the highest habitus is herbs $(31.25 \%)$. The most commonly used part is the root $(28.13 \%)$, the form of single ingredients (53\%) by boiling processing (74.36\%), the administration is orally (77.5\%) with a frequency of use three times a day (75\%). The study results proved that traditional healers in Karya Bakti Village were still using medicinal plants as tonics.
\end{abstract}

Keywords: medicinal plants, tonic, traditional healers

\section{PENDAHULUAN}

Pemanfaatan tumbuhan sebagai obat tradisional merupakan salah satu cara yang digunakan oleh masyarakat untuk mengatasi masalah kesehatan, dan hal ini telah dilakukan secara turun temurun (Gunadi et al. 2017). Masyarakat sering kali menggunakan pengobatan yang dilakukan secara tradisional karena tumbuhan obat mudah didapatkan dan tidak ada efek samping dalam pengobatan (Rianti et al. 2019). Tumbuhan selain digunakan sebagai obat juga digunakan untuk menjaga kondisi kesehatan seperti memperkuat fungsi organ tubuh
(Rahman et al. 2019). Menurut Gotti et al. (2014) dan Sunarti et al. (2016) tonik dapat berupa obat modern atau tradisional yang berkemampuan untuk menormalkan atau menguatkan fungsi organ tubuh serta meningkatkan vitalitas tubuh.

Berbagai system organ tubuh seperti jantung, pencernaan, saraf serta system reproduksi dapat diperkuat dengan menggunakan tonik (Effertha $e t$ al. 2016). Beberapa khasiat tonik yang dikategorikan dapat meningkatkan fungsi organ yaitu: obat kuat untuk vitalitas pria, penambah nafsu makan, meningkatkan sistem pencernaan 
(mengatasi sembelit dan susah buang air kecil), penambah darah, menguatkan rahim atau kandungan (Gotti et al. 2014).Tonik untuk mengatasi rasa lelah, rasa lelah dapat terjadi karena adanya aktivitas fisik atau mental, gejala yang timbul akibat rasa kelelahan ini seperti: nyeri pada otot, nyeri sendi, nyeri tenggorokan, demam ringan dan nyeri kelenjar (Liu et al. 2013). Tonik untuk perawatan paska melahirkan digunakan oleh wanita untuk: mengempiskan perut, mengurangi rasa sakit atau nyeri paska melahirkan, memulihkan kondisi kulit perut, memberikan rasa hangat dan nyaman, memperlancar keluarnya darah nifas, membersihkan rahim dan mempercepat penyembuhan luka pada organ reproduksi (Hikmat et al. 2011; Fuadi 2017).

Masyarakat di Desa Karya Bakti Kecamatan Sungai Betung Kabupaten Bengkayang dalam kehidupan sehariharinya masih memanfaatkan potensi alam yang ada di sekitar lingkungan tempat tinggalnya. Hal ini dibuktikan dengan masih terdapatnya pengobat tradisional yang biasa disebut dengan dukun yang menggunakan tumbuhan sebagai bahan dalam pengobatan tradisional. Dukun di Desa Karya Bakti membantu masyarakat desa dalam mengobati berbagai penyakit. Salah satu jenis pengobatan yang diberikan adalah memberikan ramuan tonik. Berdasarkan hal tersebut penelitian ini dilakukan guna mendokumentasikan pengetahuan dukun tradisional di Desa Karya Bakti mengenai penggunaan tumbuhan sebagai tonik.
Penelitian ini bertujuan untuk menganalisis tentang pemanfaatan tumbuhan obat tradisional yang berpotensi sebagai tonik yang digunakan oleh pengobat tradisional atau dukun di Desa Karya Bakti Kecamatan Sungai Betung Kabupaten Bengkayang. Manfaat penelitian ini diharapkan dapat memberikan informasi tentang jenis-jenis dan manfaat tumbuhan yang berpotensi sebagai tonik yang digunakan oleh masyarakat secara tradisional.

\section{METODE PENELITIAN}

Penelitian dilaksanakan di Desa Karya Bakti Kecamatan Sungai Betung Kabupaten Bengkayang. Alat yang digunakan adalah peta lokasi penelitian, kamera, tally sheet, kuisioner, buku identifikasi tumbuhan obat, alat rekaman, alat tulis menulis. Objek penelitian adalah masyarakat dan tumbuhan obat di Dusun Desa Karya Bakti Kecamatan Sungai Betung Kabupaten Bengkayang. Penelitian dilakukan dengan metode survei, pengumpulan data dilakukan dengan cara wawancara, dan pemilihan responden dilakukan dengan menggunakan metode snowball sampling.

Data tumbuhan obat yaitu nama lokal, habitus, lokasi pengambilan sampel, budidaya/liar, manfaatnya dalam menyembuhkan penyakit tonik, bentuk ramuan, bagian yang digunakan, cara penggunaan, cara pengolahan dan frekuensi penggunaan. Adapun analisis data terhadap pemanfaatan masyarakat sebagai tonik meliputi nama lokal, 
nama latin, famili, habitus, bentuk ramuan, kegunaan, bagian yang digunakan, cara pengolahan, cara penggunaan, waktu pemanenan, frekuensi penggunaan, lokasi pengambilan sampel, dan gambar tumbuhan obat. Berdasarkan data tumbuhan obat yang diperoleh selanjutnya dilakukan analisis data secara deskriptif, tabulasi data dan grafik.

\section{HASIL DAN PEMBAHASAN}

Wawancara dilakukan pada 2 orang dukun atau pengobat tradisional di Desa Karya Bakti, 2 orang dukun tersebut terdiri atas 1 orang laki-laki dan 1 orang perempuan. Adapun tumbuhan obat yang dimanfaatkan oleh dukun kampung dalam membuat ramuan tonik yaitu sebanyak 32 jenis yang terdiri dari 25 famili. Data tumbuhan obat yang meliputi nama lokal, nama latin, famili, habitus, bentuk ramuan, bagian yang digunakan, cara pengolahan, cara penggunaan, frekuensi penggunaan dan kegunaan akan ditampilkan pada Tabel 1 dan Tabel 2.

\section{Famili Tumbuhan Obat}

Jenis tumbuhan obat yang paling banyak digunakan oleh dukun adalah famili dari Zingiberaceae sebanyak 6 jenis (19\%), Apiaceae dan Piperaceae masing-masing sebanyak 2 jenis (6\%), dan famili terendah yaitu: Acanthaceae, Amaryllidaceae,

Apocynaceae,

Araceae, Arecaceae, Asteraceae, Costaceae, Dilleniaceae,

Euphorbiaceae, Fabaceae, Laminaceae, Lauraceae, Melastomataceae, Menispermaceae, Myristicaceae, Myrtaceae, Phyllanthaceae, Poaceae, Ranunculaceae, Rubiaceae, Urticaceae, dan Vitaceae sebanyak 1 jenis (3,03\%). Famili dari tumbuhan Zingiberaceae merupakan tumbuhan yang dapat digunakan untuk obat bagian dalam tubuh dan luar tubuh, selain digunakan untuk bahan pengobatan spesies famili Zingiberaceae juga digunakan untuk penambah rasa nikmat pada masakan, untuk lebih jelasnya persentase jenis tumbuhan obat berdasarkan famili dapat dilihat pada Gambar 1. 


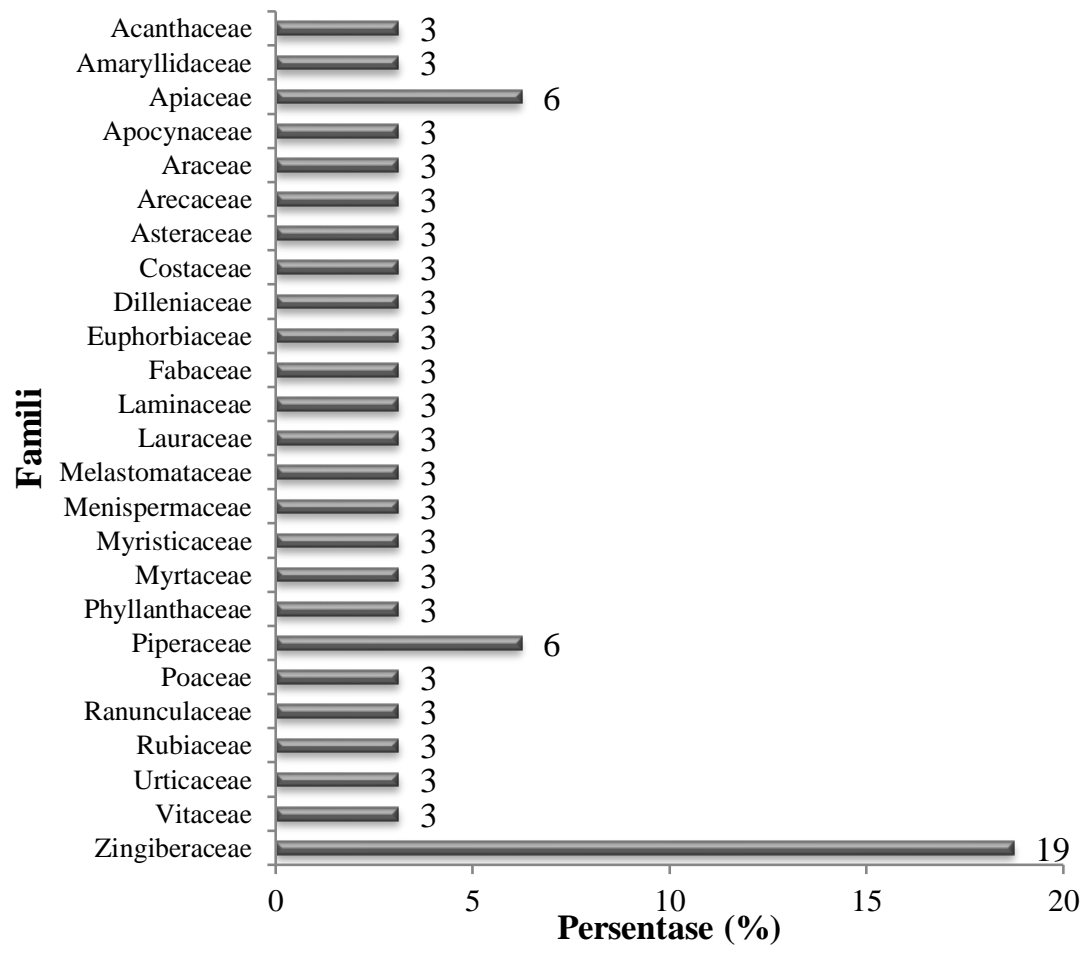

Gambar 1. Famili tumbuhan yang dimanfaatkan sebagai obat (Family of plants used as medicine)

Hasil penelitian Takoy (2013), di Desa Ensabang Kecamatan Sepauk Kabupaten Sintang dan penelitian Tantri et al. (2019), di Desa Pangkalan Buton Kabupaten Kayong Utara, menunjukan famili Zingiberaceae merupakan famili yang paling banyak digunakan oleh masyarakat seperti jahe merah, kunyit dan kencur berkhasiat untuk pasca persalinan, kunyit putih berkhasiat untuk radang tenggorokan, temulawak berkhasiat perut kembung, temu hitam berhasiat penyakit kulit.
Zingiberaceae merupakan tumbuhan yang bisa tumbuh di berbagai jenis tanah dan mudah dalam pembudidayaannya.

\section{Habitus Tumbuhan Obat}

Tumbuhan yang paling banyak dimanfaatkan oleh dukun yaitu habitusnya adalah herba sebanyak 10 jenis $(31,25 \%)$, sedangkan yang paling sedikit dimanfaatkan adalah tumbuhan dengan habitus semak 4 jenis (12,5\%), selengkapnya dapat dilihat pada Gambar 2. 


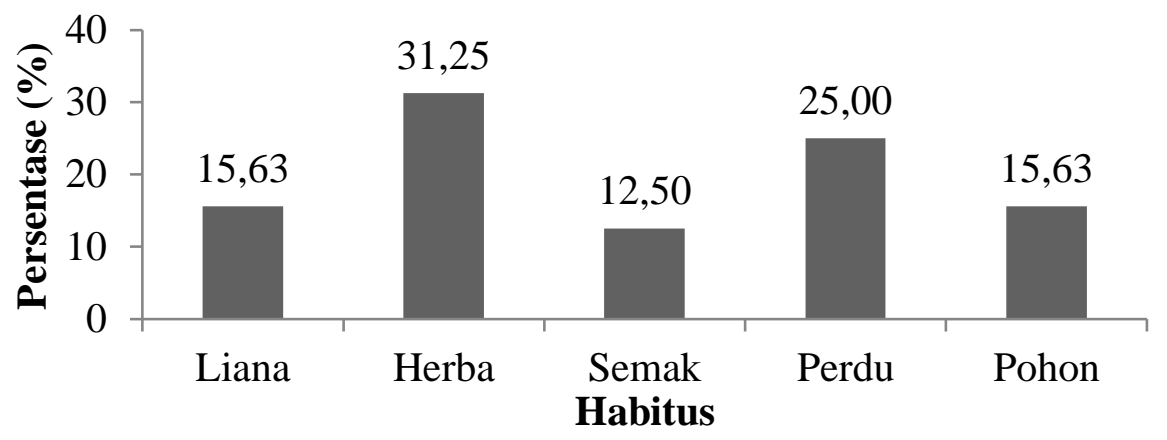

\section{Gambar 2. Habitus tumbuhan obat (Habitus of medicinal plants)}

Menurut penelitian Arsyad (2018), di Desa Sidorejo Kecamatan Tamban Kabupaten Barito Kuala menunjukan bahwa habitus yang paling banyak digunakan oleh masyarakat yaitu habitus herba. Penelitian Meliki et al. (2013), di Desa Beringin Kabupaten Sintang Kalimantan Barat menyatakan bahwa tumbuhan herba memiliki batang lunak dan tidak membentuk kayu, tumbuhan herba umumnya mudah ditemukan sehingga masyarakat lebih banyak memanfaatkannya untuk bahan pangan, pewarna, kosmetik, kerajinan, budaya, dan obat tradisional.

\section{Bagian Tumbuhan yang Digunakan}

Bagian tumbuhan yang digunakan oleh dukun sebagai ramuan tonik dapat berupa akar, rimpang, batang, daun, bunga, buah dan biji. Bagian tumbuhan yang paling banyak digunakan adalah akar yaitu 9 jenis $(28,13 \%)$, sedangkan yang paling sedikit adalah umbi, kulit, daun dan bunga yaitu masing-masing 1 jenis $(3,13 \%)$, untuk lebih jelasnya persentase jenis tumbuhan obat berdasarkan bagian yang digunakan dapat dilihat pada Gambar 3.

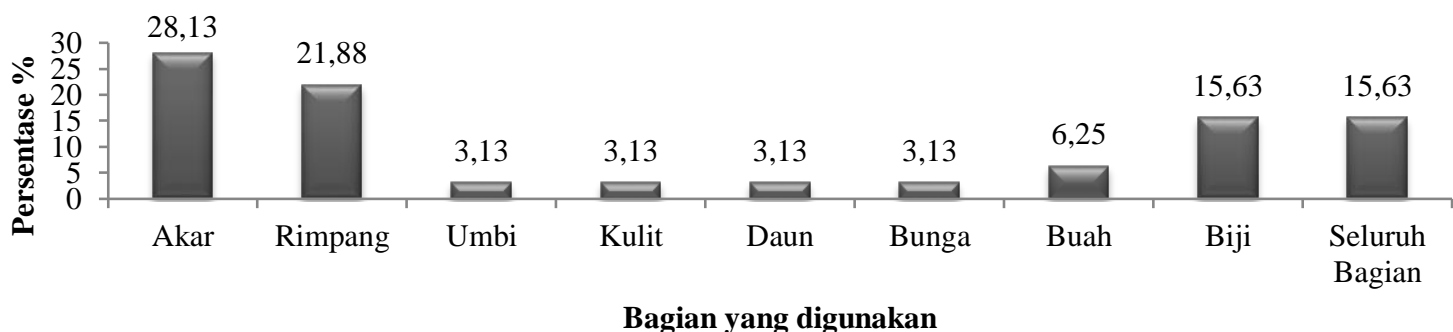

Gambar 3. Bagian tumbuhan yang digunakan sebagai tonik (Parts of a plant used as a tonic)

Dukun di Desa Karya Bakti memanfaatkan akar palado (F. tinctoria miers) untuk meningkatkan vitalitas pria serta meningkatkan sistem pencernaan. Penelitian yang dilaporkan oleh Utami et al. (2015) terhadap akar dan batang dari $F$. tinctoria miers membuktikan bahwa bagian tumbuhan 
dari akar palado ini mengandung senyawa furanoditerpenoid dan alkaloid yang berpotensi untuk memiliki aktivitas antioksidan, antiinflamasi, hepatoproteksi, antiplasmodial dan sitotoksik.

\section{Bentuk Ramuan Tumbuhan Obat}

Tumbuhan obat berdasarkan bentuk ramuannya yang paling banyak digunakan yaitu tunggal sebanyak 17 jenis (53\%) sementara bentuk ramuan campur sedikit rendah yaitu sebanyak 15 jenis (47\%), untuk ramuan campuran yang digunakan dukun biasanya menggunakan madu, telur, susu, gula pasir dan gula merah, untuk lebih jelasnya persentase jenis tumbuhan obat berdasarkan bentuk ramuan dapat dilihat pada Gambar 4.

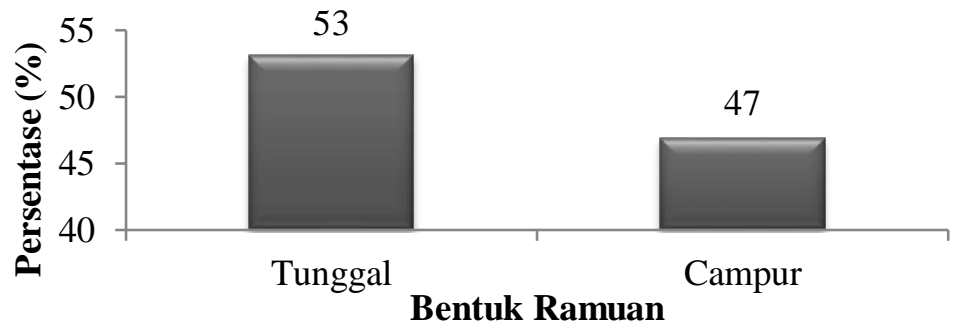

\section{Gambar 4. Bentuk ramuan tumbuhan obat (Forms of medicinal herbs)}

Hasil penelitian Efremila et al. (2015), etnis Suku Dayak di Desa Kayu Tanam Kecamatan Mandor Kabupaten Landak yang menyatakan bahwa bentuk ramuan tumbuhan obat yang banyak digunakan yaitu tunggal dan cara pengelolahannya masih tradisional. Tumbuhan obat dukun dalam bentuk ramuan tunggal tidak menggunakan campuran tumbuhan obat yang lainnya dikarenakan dipercaya dapat mengobati

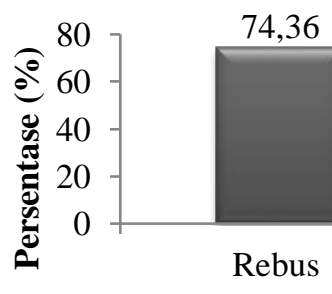

\section{Gambar 5. Cara pengolahan tumbuhan obat (Method of processing medicinal}

plants)

Hasil penelitian Sari et al. (2015), Desa Ribau Kecamatan Kapuas Kabupaten Sanggau juga menunjukan suatu jenis penyakit yang terkait dengan tonik.

\section{Cara Pengolahan Tumbuhan Obat}

Tumbuhan obat yang digunakan berdasarkan cara direbus paling banyak digunakan yaitu sebanyak 29 jenis $(74,36 \%)$ sementara cara pengolahan yang paling sedikit yaitu parut 2 jenis $(5,13 \%)$, untuk lebih jelasnya jumlah jenis berdasarkan cara pengolahan dapat dilihat pada Gambar 5.

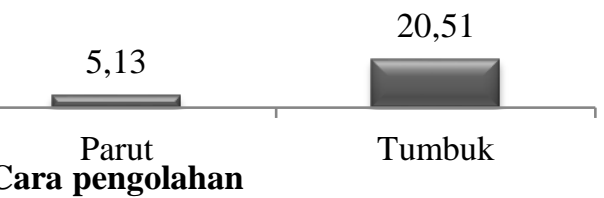


melaporkan bahwa direbus merupakan cara yang umum dilakukan oleh masyarakat dalam mengkonsumsi obat yang berasal dari tanaman karena cara ini merupakan metode yang mudah dilakukan dan menggunakan alat-alat sederhana.

\section{Cara Penggunaan Tumbuhan Obat}

Tumbuhan obat berdasarkan cara penggunaannya ada 4 yaitu tempel,

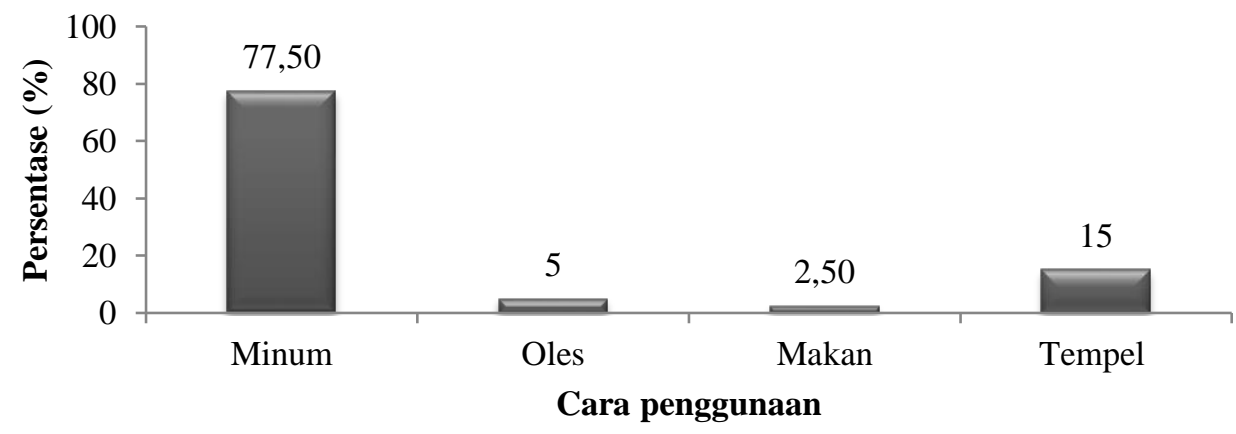

\section{Gambar 6. Cara penggunaan tumbuhan obat (How to use medicinal plants)}

Penggunaan tumbuhan obat dukun dengan cara diminum digunakan untuk pengobatan dari dalam tubuh, pengobatan dengan cara diminum dapat menunjukan reaksi yang cepat dalam penyembuhan, hal ini dikarenakan kandungan senyawa aktif pada tumbuhan yang larut pada air cepat di serap oleh tubuh. Hasil serupa juga dilaporkan Gunadi et al. (2017), etnis dayak di Desa Gerantung Kecamatan Monterado Kabupaten Bengkayang, penggunaan dengan cara diminum ternyata lebih banyak dimanfaatkan masyarakat. minum, gosok, dan makan, tumbuhan obat yang paling banyak digunakan yaitu minum sebanyak 31 jenis (77,50\%), sedangkan yang paling sedikit digunakan yaitu makan sebanyak 1 jenis (2,50\%), untuk lebih jelasnya persentase jenis tumbuhan obat berdasarkan cara pengolahan dapat dilihat pada Gambar 6.

\section{Frekuensi Penggunaan Tumbuhan Obat}

Frekuensi penggunaan tumbuhan obat yang dilakukan dukun yang paling banyak yaitu $3 \times 1$ hari dari 24 jenis (75\%), dukun menganjurkan dengan sistem aturan frekuensi $3 \times 1$ hari dapat memulihan kondisi tubuh dengan standar frekuensi yang normal, sedangkan frekuensi penggunaan tumbuhan obat yang paling sedikit adalah 2x1 hari dari 8 jenis (25\%), untuk lebih jelasnya persentase jenis tumbuhan obat berdasarkan waktu pemanenan dapat dilihat pada Gambar 7. 


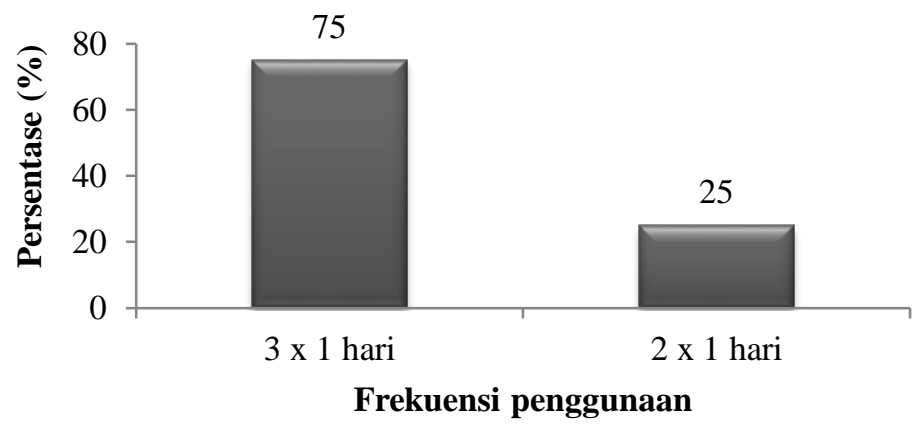

Gambar 7. Frekuensi penggunaan tumbuhan obat (Frequency of use of medicinal plants)

Dukun sering kali menggunakan frekuensi penggunaan tumbuhan obat sebanyak 3x1 dalam sehari, hal ini karena tumbuhan obat yang digunakan oleh dukun memiliki dosis yang rendah dan tidak memiliki efek samping dalam penggunaannya. Dukun kampung percaya bahwa dalam penggunaaan tumbuhan obat tradisional $3 \times 1$ dalam sehari dapat menunjukan hasil pengobatan yang memuaskan untuk mengobati penyakit terkait tonik.

\section{KESIMPULAN DAN SARAN}

Hasil penelitian menunjukan bahwa tumbuhan obat yang dimanfaatkan dukun sebanyak 32 jenis, yang termasuk kedalam 25 famili. Famili tumbuhan obat yang paling banyak dimanfaatkan dukun yaitu Zingiberaceae sebanyak 6 jenis dengan persentase (19\%). Persentase habitus tertinggi tumbuhan obat dukun yaitu herba $(31,25 \%)$. Bagian tumbuhan yang paling banyak digunakan dukun sebagai obat yaitu akar (28,13\%). Bentuk ramuan tumbuhan obat dukun yang paling banyak digunakan yaitu tunggal (53\%). Cara pengolahan tumbuhan obat dukun yang paling banyak digunakan yaitu rebus $(74,36 \%)$. Cara penggunaan tumbuhan obat dukun yang paling banyak digunakan yaitu diminum (77,50\%). Frekuensi Penggunaan tumbuhan obat dukun yang paling banyak digunakan yaitu 3x1 hari dari 24 jenis $(75 \%)$.

Perlu adanya penelitian lanjutan untuk menguji secara ilmiah tumbuhan yang memiliki nilai pemanfaatan yang tinggi. Perlu adanya pembudidayaan tumbuhan obat yang dapat dimanfaatkan oleh seluruh masyarakat di Desa Karya Bakti Kecamatan Sungai Betung Kabupaten Bengkayang.

\section{UCAPAN TERIMAKASIH}

Penulis mengucapkan terimakasih kepada pemerintah Desa Karya Bakti dan dukun tradisional yang telah berpartisipasi dalam penelitian ini.

\section{DAFTAR PUSTAKA}

Arsyad M. 2018. Studi Etnobotani Tumbuhan Obat Masyarakat Desa Sidorejo Kecamatan Tamban Kabupaten Barito Kuala. Jurnal Insan Farmasi Indonesia. 1 (1) : 85-95

Effertha T, Shanb L, dan Zhangb ZW. 2016. Tonic Herbs And Herbal Mixtures In Chinese Medicine. World J Tradit Chin Med. 2 (1) : 10-25 
Efremila, Wardenaar E, dan Sisillia L. 2015. Studi Etnobotani Tumbuhan Obat Oleh Etnis Suku Dayak Di Desa Kayu Tanam Kecamatan Mandor Kabupaten Landak. Jurnal Hutan Lestari. 3 (2) : 234246

Fuadi TM. 2017. Etnobotani Dan Identifikasi Tumbuhan Obat Bagi Ibu Pasca Melahirkan Di Desa Krueng Kluet Kecamatan Kluet Utara Aceh Selatan. Jurnal Fkip Biologi Universitas Abulyatama. Hal : 280-288

Gotti AP, Melzer J, and Saller R. 2014. An Approach to the Concept of Tonic: Suggested Definitions and Historical Aspects. Essay Forsch Komplementmed. 2 (1) : 413-417

Gunadi D, Oramahi HA, dan Tavita GE. 2017. Studi Tumbuhan Obat Pada Etnis Dayak Di Desa Gerantung Kecamatan Monterado Kabupaten Bengkayang. Jurnal Hutan Lestari. 5 (2) : 425 - 436

Hikmat A, Zuhud EAM, Siswoyo, Sandra E, dan Sari RK. 2011. Revitalisasi Konservasi Tumbuhan Obat Keluarga (Toga) Guna Meningkatkan Kesehatan Dan Ekonomi Keluarga Mandiri Di Desa Contoh Lingkar Kampus Ipb Darmaga Bogor. Jurnal Ilmu Pertanian Indonesia. 16 (2) : 7180

Liu DD, Ji XW, dan Li RW. 2013. Effects of Siraitia grosvenorii Fruits Extracts on Physical Fatigue in Mice. Iranian Journal of Pharmaceutical Research. 12 (1) : 115-121

Marpaung DRAK. 2018. Tumbuhan Obat Dan Kearifan Lokal Masyarakat Di Sekitar Kawasan
Tnbg, Desa Sibanggor Julu, Kabupaten Mandailing Natal. Jurnal Biosains 4 (2) : 85-91

Meliki, Linda R, dan Irwan L. 2013. Etnobotani Tumbuhan Obat oleh Suku Dayak Iban Desa Tanjung Sari Kecamatan Ketungau Tengah Kabupaten Sintang. Jurnal Biologi. 2 (3) : 129-135

Puspitasari Ad, dan Prayogo Ls. 2016. Pengaruh Waktu Perebusan Terhadap Kadar Flavonoid Total Daun Kersen (Muntingia calabura). Jurnal Inovasi Teknik Kimia. 1 (2) : 104-108

Rianti Y, Purwati, dan Wahdina. 2019. Potensi Tumbuhan Obat Di Desa Bemban Kawasan Hutan Lindung Gunung Ambawang Kecamatan Kubu Kabupaten Kubu Raya. Jurnal Hutan Lestari. 7 (3) : 1470-1477

Rahman K, Wardenaar E, dan Mariani Y. 2019. Identifikasi Jenis Dan Pemanfaatan Tumbuhan Obat Di Hutan Tembawang Oleh Masyarakat Kelurahan Beringin Kecamatan Kapuas Kabupaten Sanggau. Jurnal Hutan Lestari. 7 (1) : 44-55

Sari A, Linda R, dan Lovadi I. 2015. Pemanfaatan Tumbuhan Obat Pada Masyarakat Suku Dayak Jangkang Tanjung Di Desa Ribau Kecamatan Kapuas Kabupaten Sanggau. Jurnal Protobiont. 4 (2) : $1-8$

Sunarti, Keswara YD, dan Purnamasari ND. 2016. Tonic Effects Test Of Pegagan (Centella Asiatica L.) Syrups On White Male Mice. Jurnal Farmasi Indonesia. 8 (2) : 167-173 
Takoy DM, Linda R, dan Lovadi I. 2013. Tumbuhan Berkhasiat Obat Suku Dayak Seberuang Di Kawasan Hutan Desa Ensabang Kecamatan Sepauk Kabupaten Sintang. Jurnal Protobiont. 2 (3) : 122-128

Tantri S, Dewantara I, dan Wardenaar E. 2019. Pemanfaatan Tumbuhan Obat Oleh Masyarakat Sekitar
Hutan Di Desa Pangkalan Buton Kabupaten Kayong Utara. Jurnal Hutan Lestari. 7 (3) : 1186-1197

Utami R, Sandi NH, Hasti S, dan Delvia S. 2015. Uji Aktivitas Antidiabetes Ekstrak Etanol dari Akar Dan Batang Tumbuhan Sekunyit (Fibraurea tinctoria Lour). Jurnal Farmasi Indonesia. 7 (4): 216-222 
JURNAL HUTAN LESTARI (2020)

Vol. 8 (3): 640 - 652

\section{Lampiran}

Tabel 1. Data Tumbuhan Obat yang Dimanfaatkan oleh Dukun yang Berpotensi Sebagai Tonik di Desa Karya Bakti Kecamatan Sungai Betung Kabupaten Bengkayang (Data on medicinal plants used by traditional healers with potential as tonics in Karya Bakti Village Sungai Betung Sub-District Bengkayang Districts)

\begin{tabular}{|c|c|c|c|c|c|c|}
\hline No & Nama Lokal & Nama Latin & Famili & Habitus & Bentuk Ramuan & Waktu Pemanenan \\
\hline 1 & Ahnyam tidur & Phyllanthus reticulatus Poir & Phyllanthaceae & Semak & Tunggal & Setiap waktu \\
\hline 2 & Asam jawa & Tamarindus indica $\mathrm{L}$ & Fabaceae & Pohon & Campur & Setiap waktu \\
\hline 3 & Bamali & Leea indica (Burm.f.) Merr & Vitaceae & Perdu & Campur & Setiap waktu \\
\hline 4 & Bangkayak & Justicia gendarussa Burm.f & Acanthaceae & Semak & Tunggal & Setiap waktu \\
\hline 6 & Buant & Dillenia suffruticosa (Griff. ex Hook) Martelli & Dilleniaceae & Perdu & Tunggal & Setiap waktu \\
\hline 7 & Buntan & Cocos nucifera $\mathrm{L}$ & Arecaceae & Pohon & Campur & Setiap waktu \\
\hline 8 & Cakur & Kaempferia galanga $\mathrm{L}$ & Zingiberaceae & Herba & Campur & Setiap waktu \\
\hline 9 & Cengkeh & Syzygium aromaticum $\mathrm{L}$ & Myrtaceae & Perdu & Campur & Setiap waktu \\
\hline 11 & Jintan putih & Cuтіпит сутіпит $\mathrm{L}$ & Apiaceae & Liana & Campur & Setiap waktu \\
\hline 12 & Kalamabo & Blumea balsamifera $\mathrm{L}$ & Asteraceae & Perdu & Tunggal & Setiap waktu \\
\hline 13 & Karungan merah & Jatropha gossypifolia $\mathrm{L}$ & Euphorbiaceae & Perdu & Tunggal & Setiap waktu \\
\hline 14 & Kayu manis & Cinnaтотит verum J.Presl & Lauraceae & Pohon & Campur & Setiap waktu \\
\hline 15 & Ketumbar & Coriandrum sativum $\mathrm{L}$ & Apiaceae & Herba & Campur & Setiap waktu \\
\hline 16 & Kunyit & Curcuma longa $\mathrm{L}$ & Zingiberaceae & Herba & Campur & Setiap waktu \\
\hline 17 & Lada & Piper ningrum $\mathrm{L}$ & Piperaceae & Liana & Campur & Setiap waktu \\
\hline 18 & Lengkuas & Alpinia galanga $\mathrm{L}$ & Zingiberaceae & Herba & Campur & Setiap waktu \\
\hline 19 & Marawat & Vitex pinnata $\mathrm{L}$ & Laminaceae & Perdu & Tunggal & Setiap waktu \\
\hline 20 & Mengkudu & Morinda citrifolia $\mathrm{L}$ & Rubiaceae & Perdu & Tunggal & Setiap waktu \\
\hline 22 & Pala & Myristica fragrans Houtt & Myristicaceae & Pohon & Tunggal & Setiap waktu \\
\hline 23 & Paldo & Fibraurea tinctoria Lour & Menispermaceae & Liana & Tunggal & Setiap waktu \\
\hline 24 & Palai & Alstonia scholaris $\mathrm{L}$ & Apocynaceae & Pohon & Tunggal & Setiap waktu \\
\hline 25 & Riak merah & Zingiber officinale Var. Rubrum & Zingiberaceae & Herba & Campur & Setiap waktu \\
\hline 26 & Riak putih & Zingiber officinale Var. Amarum & Zingiberaceae & Herba & Campur & Setiap waktu \\
\hline 27 & Tabu amot & Cheilocostus speciosus (J.Konig) C.Specht & Costaceae & Semak & Tunggal & Setiap waktu \\
\hline 28 & Takang & Melastoma malabathricum $\mathrm{L}$ & Melastomataceae & Semak & Tunggal & Setiap waktu \\
\hline 29 & Tampajarak & Leucosyke capitellata (Poir.) Wedd & Urticaceae & Perdu & Tunggal & Setiap waktu \\
\hline 30 & Temulawak & Curcuma xanthoriza Roxb & Zingiberaceae & Herba & Campur & Setiap waktu \\
\hline 31 & Tungun merah & Homalomena occulta (Lour.) Schott & Araceae & Herba & Tunggal & Setiap waktu \\
\hline 32 & Uwit merah & Piper ornatum $\mathrm{L}$ & Piperaceae & Liana & Tunggal & Setiap waktu \\
\hline
\end{tabular}


JURNAL HUTAN LESTARI (2020)

Vol. 8 (3): 640 - 652

\section{Lampiran}

Tabel 2. Data Pemanfaatan Tumbuhan Obat yang Dimanfaatkan oleh Dukun yang Berpotensi Sebagai Tonik di Desa Karya Bakti Kecamatan Sungai Betung Kabupaten Bengkayang (Data on Utilization of Medicinal Plants Utilized by Traditional Shamans as Potential Tonics in Karya Bakti Village Sungai Betung Sub-District Bengkayang Districts)

\begin{tabular}{|c|c|c|c|c|c|c|c|c|}
\hline No & Nama Lokal & Kegunaan & $\begin{array}{l}\text { Bagian yang } \\
\text { Digunakan }\end{array}$ & $\begin{array}{l}\text { Cara } \\
\text { Pengolahan }\end{array}$ & $\begin{array}{l}\text { Cara } \\
\text { Penggunaan }\end{array}$ & $\begin{array}{l}\text { Frekuensi } \\
\text { Penggunaan }\end{array}$ & $\begin{array}{l}\text { Jumlah } \\
\text { Pengguna }\end{array}$ & $\mathbf{U V}$ \\
\hline 1 & Ahnyam tidur & Meningkatkan sistem pencernaan, & $\begin{array}{l}\text { Seluruh } \\
\text { Bagian }\end{array}$ & Rebus & Minum & $3 \times 1$ hari & 114 & 0,52 \\
\hline 2 & Asam jawa & $\begin{array}{l}\text { Vitalitas pria, penambah nafsu makan, meningkatkan } \\
\text { sistem pencernaan, demam, memulihkan kulit perut } \\
\text { pasca persalinan }\end{array}$ & Buah & Rebus & Minum & $3 \times 1$ hari & 49 & 0,22 \\
\hline 3 & Bamali & $\begin{array}{l}\text { Vitalitas pria, mengurangi nyeri pasca persalinan, } \\
\text { penyembuhan luka rahim pasca persalinan }\end{array}$ & $\begin{array}{l}\text { Seluruh } \\
\text { Bagian }\end{array}$ & Rebus & Minum & $3 \times 1$ hari & 115 & 0,52 \\
\hline 4 & Bangkayak & Vitalitas pria, nyeri sendi, demam & $\begin{array}{l}\text { Seluruh } \\
\text { Bagian }\end{array}$ & $\begin{array}{l}\text { Rebus, } \\
\text { Tumbuk }\end{array}$ & Minum, Tempel & $3 \times 1$ hari & 61 & 0,28 \\
\hline 5 & Bawang merah & Vitalitas pria, nyeri otot, demam & Umbi & $\begin{array}{l}\text { Ditumbuk, } \\
\text { Rebus }\end{array}$ & Oles, Minum & $3 \times 1$ hari & 99 & 0,45 \\
\hline 6 & Buant & $\begin{array}{l}\text { Mengurangi nyeri pasca persalinan, penyembuhan } \\
\text { luka rahim pasca persalinan }\end{array}$ & Akar & Rebus & Minum & $3 \times 1$ hari & 122 & 0,55 \\
\hline 7 & Buntan & $\begin{array}{l}\text { Vitalitas pria, meningkatkan sistem pencernaan, } \\
\text { penguat kandungan, pengempis perut pasca } \\
\text { persalinan }\end{array}$ & Buah & Parut & Minum, Makan & $3 \times 1$ hari & 109 & 0,49 \\
\hline 8 & Cakur & Vitalitas pria, nyeri otot, nyeri sendi & Rimpang & Tumbuk & Minum & $3 \times 1$ hari & 132 & 0,60 \\
\hline 9 & Cengkeh & Vitalitas pria & Bunga & Rebus & Minum & $2 \times 1$ hari & 4 & 0,02 \\
\hline 10 & Jintan hitam & Vitalitas pria & Biji & Rebus & Minum & $2 \times 1$ hari & 5 & 0,02 \\
\hline 11 & Jintan putih & Nyeri otot, nyeri sendi, vitalitas pria & Biji & Rebus & Minum & $2 \times 1$ hari & 30 & 0,14 \\
\hline 12 & Kalamabo & Vitalitas pria & Akar & Rebus & Minum & $2 \times 1$ hari & 63 & 0,29 \\
\hline 13 & Karungan merah & $\begin{array}{l}\text { Meningkatkan sistem pencernaan, nyeri otot, nyeri } \\
\text { sendi, demam }\end{array}$ & $\begin{array}{l}\text { Seluruh } \\
\text { Bagian }\end{array}$ & $\begin{array}{l}\text { Tumbuk, } \\
\text { Rebus }\end{array}$ & Tempel, Minum & $3 \times 1$ hari & 72 & 0,33 \\
\hline 14 & Kayu manis & Penambah nafsu makan & Kulit & Rebus & Minum & $2 \times 1$ hari & 36 & 0,16 \\
\hline 15 & Ketumbar & $\begin{array}{l}\text { Nyeri otot, nyeri sendi, hangatkan tubuh pasca } \\
\text { persalinan }\end{array}$ & Biji & Rebus & Minum & $3 \times 1$ hari & 29 & 0,13 \\
\hline 16 & Kunyit & $\begin{array}{l}\text { Penambah nafsu makan, penguat kandungan, } \\
\text { memulihkan kulit perut pasca persalinan, } \\
\text { membersihkan rahim pasca persalinan }\end{array}$ & Rimpang & Parut, Rebus & Oles, Minum & $3 \times 1$ hari & 120 & 0,54 \\
\hline 17 & Lada & $\begin{array}{l}\text { Penambah nafsu makan, pengempis perut pasca } \\
\text { persalinan, hangatkan tubuh pasca persalinan }\end{array}$ & Biji & Rebus & Minum & $3 \times 1$ hari & 41 & 0,19 \\
\hline 18 & Lengkuas & $\begin{array}{l}\text { Penambah nafsu makan, meningkatkan sistem } \\
\text { pencernaan, penambah darah, memulih kulit perut }\end{array}$ & Rimpang & Rebus & Minum & $2 \times 1$ hari & 50 & 0,23 \\
\hline
\end{tabular}


JURNAL HUTAN LESTARI (2020)

Vol. 8 (3): 640 - 652

\section{Lampiran}

\begin{tabular}{|c|c|c|c|c|c|c|c|c|}
\hline No & Nama Lokal & Kegunaan & $\begin{array}{l}\text { Bagian yang } \\
\text { Digunakan }\end{array}$ & $\begin{array}{l}\text { Cara } \\
\text { Pengolahan }\end{array}$ & $\begin{array}{l}\text { Cara } \\
\text { Penggunaan }\end{array}$ & $\begin{array}{l}\text { Frekuensi } \\
\text { Penggunaan }\end{array}$ & $\begin{array}{l}\text { Jumlah } \\
\text { Pengguna }\end{array}$ & $\mathbf{U V}$ \\
\hline & & $\begin{array}{l}\text { pasca persalinan, lancarkan keluarnya darah pasca } \\
\text { persalinan }\end{array}$ & & & & & & \\
\hline 19 & Marawat & $\begin{array}{l}\text { Meningkatkan sistem pencernaan, nyeri otot, nyeri } \\
\text { sendi, demam }\end{array}$ & Akar & Rebus & Minum & $3 \times 1$ hari & 43 & 0,19 \\
\hline 20 & Mengkudu & $\begin{array}{l}\text { Vitalitas pria, meningkatkan sistem, pencernaan, } \\
\text { demam }\end{array}$ & Akar & Rebus & Minum & $3 \times 1$ hari & 37 & 0,17 \\
\hline 21 & Padang & Meningkatkan sistem pencernaan, demam & Akar & Rebus & Minum & $3 \times 1$ hari & 67 & 0,30 \\
\hline 22 & Pala & Vitalitas pria & Biji & Rebus & Minum & $2 \times 1$ hari & 7 & 0,03 \\
\hline 24 & Palai & Meningkatkan sistem pencernaan & Akar & Rebus & Minum & $3 \times 1$ hari & 9 & 0,04 \\
\hline 25 & Riak merah & $\begin{array}{l}\text { Vitalitas pria, nyeri otot, nyeri sendi, pengempis } \\
\text { perut pasca persalinan, mengurangi nyeri pasca } \\
\text { persalinan, hangatkan tubuh pasca persalinan, } \\
\text { penyembuhan luka rahim pasca persalinan }\end{array}$ & Rimpang & $\begin{array}{l}\text { Rebus, } \\
\text { Tumbuk }\end{array}$ & Minum, Tempel & $3 \times 1$ hari & 164 & 0,74 \\
\hline 26 & Riak putih & $\begin{array}{l}\text { Vitalitas pria, penambah nafsu makan, nyeri otot, } \\
\text { nyeri sendi, pengempis perut pasca persalinan, } \\
\text { mengurangi nyeri pasca persalinan, hangatkan tubuh } \\
\text { pasca persalinan, penyembuhan luka rahim pasca } \\
\text { persalinan }\end{array}$ & Rimpang & $\begin{array}{l}\text { Rebus, } \\
\text { Tumbuk }\end{array}$ & Minum, Tempel & $3 \times 1$ hari & 170 & 0,77 \\
\hline 28 & Takang & Nyeri otot & Daun & Tumbuk & Tempel & $2 \times 1$ hari & 28 & 0,13 \\
\hline 29 & Tampajarak & Demam & Akar & Rebus & Minum & $3 \times 1$ hari & 12 & 0,05 \\
\hline 30 & Temulawak & $\begin{array}{l}\text { Vitalitas pria, nyeri otot, nyeri sendi, mengurangi } \\
\text { nyeri pasca persalinan, memulih kulit perut pasca } \\
\text { persalinan, penyembuhan luka rahim pasca } \\
\text { persalinan }\end{array}$ & Rimpang & $\begin{array}{l}\text { Rebus, } \\
\text { Tumbuk }\end{array}$ & Minum, Tempel & $3 \times 1$ hari & 104 & 0,47 \\
\hline 31 & Tungun merah & Nyeri otot, mengurangi nyeri pasca persalinan & Rimpang & Rebus & Minum & $3 \times 1$ hari & 78 & 0,35 \\
\hline 32 & Uwit merah & Membersihkan rahim pasca persalinan & $\begin{array}{l}\text { Seluruh } \\
\text { Bagian }\end{array}$ & Rebus & Minum & $3 \times 1$ hari & 41 & 0,19 \\
\hline
\end{tabular}

